navchannia / [Za red. S.D. Maksymenka, M.L. Smulson]. - K. : Vyd-vo NPU imeni M.P. Drahomanova, 2009. - T. 8. - Vyp. 6 - S. 250-259.

Sofii, 2007 - Sofii N.Z. Kontseptualni aspekty inkliuzyvnoi osvity / Inkliuzyvna shkola: osoblyvosti orhanizatsii ta upravlinnia : navchalno-metodychnyi posibnyk / Kol. Avtoriv : Kolupaieva A.A., Naida Yu.M., Sofii N.Z. ta in.; [Za red. L.I. Danylenko]. - K., 2007. - 128 s.

Statisticheskie dannyie... - Statisticheskie dannyie na sayte Organizatsii po zaschite prav rebenka [Elektronnyiy resurs]. - Rezhim dostupa : http:///www.opcr/org/english/stats_world.htm.

Pastor, 2009 - Pastor C. Analysing and federation the European assistive technology ICT industry / C. Pastor et al. // European Commission Information Society and Media. - 2009. - 188 p.

Riding, 1991 - Riding R.J. Cognitive style - an overview and integration / R.J. Riding, I. Cheema // Educat. Psychology. - 1991. - V. 11. - P. 193-215.

Rogers, 1993 - Rogers I. The Inclusion Revolution / I. Rogers. - Bloomington : Phi Delton Kappa, 1993. - 258 p.

World Bank, 2007 - World Bank, 2007. Measuring Disability Prevalence [Elektronnyiy resurs] (Raspredelenie urovnya invalidnosti. Vsemirnyiy Bank, 2007). - Rezhim dostupa: http://siteresources. worldbank.org/DISABILITY/Resources/Data/MontPrevalence.pdf.

УДК 392:502.13]:37

Валентина Скутіна, кандидат педагогічних наук, дочент кафедри географії, екології та методики викладання ДВНЗ «ПереяславХмельницький державний педагогічний університет імені Григорія Сковороди».

\section{DOI 10.31470/2308-5126-2019-45-2-108-115}

E-mail: olimp-geograf@ukr.net

ORCID 0000-0001-5023-1665

\title{
НАРОДНІ ПРИРОДООХОРОННІ ТРАДИЦІЇ ЯК СИСТЕМНЕ ПЕДАГОГІЧНЕ ЯВИЩЕ
}

У статті проаналізовано народні природоохоронні традииії як системне педагогічне явище. Обтрунтовано, що історична стійкість етносу забезпечила постійність його взаємодї з природним середовищем, в ході якої природоохоронні традиції зафіксували найбільш характерні значимі риси локальних екологічних систем, головні їх природні компоненти.

Доведено, щуо основою формування народних природоохоронних традицій є духовний характер взаємодї народу з навколишнім природним середовищем, який сформувався протягом більш ніж тисячолітнього періоду під впливом християнського світогляду.

3'ясовано системність народних природоохоронних традицій з точки зору їх функціональності та змістовності. Обтрунтовано, щзо системність народної традииії дбайливого ставлення до природного середовища зумовлена природними факторами. Цей висновок зроблений на основі того, що історична стійкість етносу забезпечила постійність його взаємодії з географічним середовищем.

Ключові слова: традииї, звичаї, народні природоохоронні традиції, народні традиції природоохоронного виховання.

The article analyzes the national nature traditions as a systemic pedagogical phenomenon. It is grounded that the historical stability of the ethnos ensured the continuity of its interaction with the natural environment, during which the nature traditions recorded the most characteristic features of local ecological systems, their main natural components.

It is proved that the basis of the formation of folk nature conservation traditions is the spiritual nature of the interaction of the people with the natural environment, which was formed during more than a thousand years under the influence of the Christian world outlook.

The systematic nature of folk nature conservation traditions is determined from the point of view of their functionality and content.

It is substantiated that the system of folk tradition of careful attitude to the natural environment is due to natural factors. This conclusion is based on the fact that the historical stability of the ethnic group ensured the continuity of its interaction with the geographical environment. During this long interaction traditions recorded the 
most characteristic, significant and persistent features of the local ecological system, the main natural components space factors, relief, soil, climate, water, flora and fauna. Environmental conservation tradition is a kind of system of systems, that is, it acts as a tradition of traditions

The essence of concepts «folk nature conservation traditions», "raditions of nature protection education in folk pedagogy» is revealed.

The structural components of the ethnic experience of folk nature conservation traditions are distinguished: spiritual (Christian outlook, Orthodox worldview); informative (knowledge about nature and ecological representations of the people); valuable (value orientations in the system «man-nature»); normative (system of installations, rules and norms of behavior in nature); activity (life in unity with nature and its Creator, ways of rational use of nature, forms of nature protection activities). education.

Keywords: traditions, customs, national nature traditions, national traditions of nature protection

Постановка проблеми. Проблема взаємодії людського суспільства і природи є однією $з$ актуальних проблем сучасності, успішне вирішення якої залежить від рівня екологічної культури кожної особистості, кожного народу та рівня суспільної свідомості в цілому. На нинішньому етапі відбувається переосмислення сутності екологічної проблеми 3 точок зору загальнолюдської та загальнонародної. Такий підхід сприяє пошуку нових оптимальних шляхів іiі вирішення на основі дослідження і відродження суспільно-історичного досвіду та культурно-педагогічних надбань нашого народу. Актуальність проблеми дослідження визначається значним науково-практичним потенціалом багатовікового народного педагогічного досвіду з природоохоронного виховання дітей та молоді, сконцентрованого у народних природоохоронних традиціях, що сформувалися у процесі тривалого історичного періоду.

Аналіз останніх досліджень $\boldsymbol{i}$ публікацій. Грунтовні історико-педагогічні дослідження різних аспектів педагогічних поглядів народу здійснювали С. Бабишин, Т. Мацейків, В. Мосіяшенко, М. Стельмахович, С. Сявавко. В їх дослідженнях проаналізовано і узагальнено історичний досвід народу у вихованні дітей та молоді, виявлено головні ідеї, основні принципи, засоби української народної і педагогіки, особливості їх прояву в сучасних умовах.

Важливе значення для розуміння суті традицій як форм суспільного досвіду, закономірностей їх становлення та функціонування мають праці В. Афоніної, Ю. Бромлея, Е. Гірусова, М. Денисюк, В. Левченка, В. Плахова, Є. Маркаряна та інших.

Етнографічні аспекти народних традицій, пов'язаних з духовним життям та господарською діяльністю народу відображено у працях етнографів XIX XX століття Г. Булашева, О. Воропая, I. Верхратського, Б. Грінченка, М. Драгоманова, Н. Заглади, П. Іванова, 3. Кузелі, М. Максимовича, М. Могилевського, Я. Новинського, Н. Сумцова, В. Скуратівського, П. Чубинського. Педагогіку народного календаря досліджували В. Мосіяшенко, В. Кузь, Ю. Руденко, 3. Сергійчук; народні знання про природу - В. Куйбіда.

Науково-практичне значення для визначення основних шляхів i форм творчого застосування історичного досвіду народної педагогіки в сучасному екологічному вихованні школярів мають праці О. Біди, В. Вербицького, Р. Вережак, Г. Волошиної, В. Гонзуль, Р. Дуб, О. Захлєбного, І. Зверевої, І. Суравегіної, О. Кондратюк, Г. Яцук, а також дослідження А. Бегеки, Р. Науменко, Л. Різник, Л. Руденко, С. Іващенко, В. Титаренко, Л. Хоменко, З. Шевців, у яких вказується на необхідність використання народно-педагогічних засобів в екологічному вихованні 
молодих школярів на основі засвоєння народних традицій бережливого ставлення до природи.

Mema cmammi - розкрити сутність народних природоохоронних традицій як системного педагогічного явища.

Виклад основного матеріалу. 3 визнанням пріоритету загальнолюдських цінностей у вихованні підростаючих поколінь у педагогічній теорії сформувалось більш глибоке розуміння суті процесу виховання та ролі в ньому народних виховних традицій. Широке розуміння «загальної та вічної» категорії виховання включає засвоєння молодшими поколіннями життєвого досвіду взаємовідносин з природою, загальнолюдських християнських духовних цінностей. У практиці народної педагогіки цей процес відбувається в результаті сприйняття дітьми та молоддю системи народних традицій, які здійснюють постійний зв'язок між природою, народом та особистістю.

Науковий підхід до традицій полягає в тому, що вони розглядаються як об'єктивне суспільно-історичне явище, властиве не лише матеріальній, а й духовній сфері. універсальна форма збереження та механізм передачі у спадок педагогічного досвіду [Енциклопедія освіти, 2008: с. 914].

Сам термін «традиція» (traditio), у перекладі $з$ латинської - «передача», у найбільш широкому розумінні означає історичну спадкоємність об'єктивних суспільних явищ, закономірний зв'язок між минулим, сучасним і майбутнім їх станом, передбачає певну логіку в їх розвитку.

Аналіз наукових досліджень, історичних та археологічних даних свідчить про те, що природоохоронні традиції не були характерними для суспільства 3 моменту початку його існування. Історичні умови для їх виникнення склались на певному етапі суспільного розвитку. У висвітленні даного питання важливим $\epsilon$ висновок В. Афоніної, Ю. Бромлея, Е. Маркаряна про те, що головними умовами виникнення будь-якої традиції $€$ :

- наявність історичної спільності людей - виробника і носія традиції;

- необхідність закріплення результатів колективної діяльності людей;

- формування ціннісного ядра традиції [Афоніна, 1986: c. 311].

Ю. Бромлеєм обгрунтовано двосторонній характер відносин етносу i природного середовища його проживання. А це в свою чергу дозволяє розглядати етнос і середовище його проживання як певну цілісність - «етноекологічну систему» [Бромлей, 2008: с. 254].

Відповідно до вищесказаного, об’єктивні фактори становлення і розвитку досліджуваних традицій були детерміновані обома складовими етноекологічної системи - як природною, так і етнічною.

3 точки зору Ю. Бромлея та Р. Подольного, для ранніх етапів розвитку етносу, періоду його формування, була характерна найбільша залежність всіх сторін матеріальної та духовної культури від природних чинників, що пояснюється його адаптацією до своєї екологічної ніші. Рельєф, грунтово-кліматичні умови, особливості водних, мінеральних і біологічних ресурсів значним чином визначають етнічні особливості культурно-господарського розвитку: головні види трудової діяльності, землеробську та ремісничу спеціалізацію і пов'язаний 3 ними характер природокористування. Господарська спеціалізація кожного народу історично зумовлена співвідношенням в момент виникнення цієї спеціалізації двох факторів: рівня соціально-економічного розвитку та характеру природного середовища... 
В разі їх тривалої стабільності система господарства, що склалась, стає традиційною... [Бромлей, 1990: с. 48].

Опосередковано природні умови здійснюють вплив також на специфіку побуту, обрядів, звичаїв, загальноприйняті норми і правила поведінки в природі. Більшість народних традицій містять певні норми поведінки по відношенню до природи, але одні з них стають причиною порушення екологічної рівноваги, інші зберігають досвід пристосування до природних умов, врахування природних факторів у господарській діяльності, підтримання рівноваги в навколишньому природному середовищі.

Отже, не всі народні традиції $є$ природоохоронними, а лише ті, які акумулюють позитивний народний досвід гармонійного співжиття 3 природою i спрямовані на збереження навколишнього природного середовища. Для означення даних традицій ми використовуємо паралельні терміни, які мають синонімічне значення в аспекті нашої проблеми 3 певними смисловими відтінками: «народні природоохоронні традиції», «народні традиції дбайливого ставлення до природи».

Системність народної традиції дбайливого ставлення до природного середовища також зумовлена природними факторами. Цей висновок зроблений на основі того, що історична стійкість етносу забезпечила постійність його взаємодії 3 географічним середовищем. У ході цієї тривалої взаємодії традиції зафіксували найбільш характерні, значимі та стійкі риси локальної екологічної системи, головні природні компоненти - космічні фактори, рельєф, грунт, клімат, воду, рослинний і тваринний світ. Природоохоронна традиція є своєрідною системою систем, тобто виступає як традиція традицій.

Основою формування народних природоохоронних традицій є духовний характер взаємодії народу 3 навколишнім природним середовищем, який сформувався протягом більш ніж тисячолітнього історичного періоду під впливом християнського світогляду, системи цінностей, ідеалів, мотивів, поглядів і переконань, сутність яких полягає у любові до Бога, до всієї природи, створеної Творцем і до ближнього, як до самого себе.

Одночасно природоохоронні традиції відображають також суспільний характер взаємодії в системі «етнос-природа». Ця взаємодія завжди опосередкована конкретною колективною трудовою діяльністю людей. У ході активної трудової діяльності народ змінює i перетворює природу, знаходить оптимальні форми господарської діяльності в природному середовищі, емпірично виробляє способи раціонального природокористування.

У зв'язку 3 тим, що процес трудової взаємодії етносу 3 природою безперервний і у сферу виробництва постійно залучаються різноманітні природні багатства, успішний розвиток господарства стимулюється наявністю потенційних природних ресурсів, a їх виснаженість, навпаки, затримує економічний ріст i об'єктивно вимагає гармонізації взаємовідносин з природою, активізує діяльність, спрямовану на ії збереження.

Важливою особливістю народних природоохоронних традицій $є$ те, що на будь-якому етапі історичного розвитку вони прогресивні за своїм змістом і спрямованістю, втілюючи важливі моральні норми та принципи співжиття людини 3 природою, правила поведінки, які перевірені на практиці багатьма поколіннями і $є$ загальноприйнятими, традиційними. Досліджувані традиції належать до загальнонародних моральних цінностей. Вони втілюють інтереси народу в цілому, забезпечуючи не лише його існування, але й успішний історичний розвиток. 
Отже, становлення та розвиток народних природоохоронних традицій зумовлено комплексом взаємопов'язаних між собою духовних, природногеографічних та господарсько-економічних факторів.

Виходячи 3 сучасних поглядів на традиції, виділяємо такі структурні компоненти етнічного досвіду народних природоохоронних традицій:

- духовні (християнський світогляд, православне світобачення);

- інформативні (знання про природу та екологічні уявлення народу);

- ціннісні (ціннісні орієнтації в системі «Творець-людина-природа»);

- нормативні (система установок, правил і норм поведінки в природі);

- діяльнісні (життя у єдності 3 природою та ii Творцем, способи раціонального природокористування, форми природоохоронної діяльності).

Аналіз історико-педагогічної та етнографічної літератури свідчить, що вихідними для народної педагогіки були традиційні світоглядні уявлення народу про єдність та взаємовплив людини і природи, а складовою частиною педагогічного ідеалу - відповідальне, бережливе ставлення до природи рідного краю. Сдність народу з природою була помічена переважною більшістю географів та етнографів XVIII - початку XX ст.

Функціональний аналіз народних виховних традицій дозволяє виділити їх складові елементи - народні традиції, звичаї обряди, свята, символи, (ритуали) усну народну творчість. У народній педагогічній системі останні виступають як головні засоби виховання та навчання особистості.

Основою природоохоронного виховання дітей та молоді впродовж століть були народні природоохоронні традиції, через які передавались знання про природу, екологічні уявлення народу, його погляди та цінності в системі «Творець - людина природа». Традиції регулювали духовні цінності особистості, необхідні для позитивної поведінки у природному середовищі. Через сприйняття молоддю природоохоронних традицій здійснювався вплив на свідомість, дітей та молоді. Відбувалось формування стійких поглядів і переконань в необхідності дбайливого ставлення до природи та формування відповідних якостей особистості.

Будучи результатом акумуляції етнічного досвіду, традиції виступали для молодших поколінь системою моральних установок та ціннісних орієнтацій. Для означення найвищих цінностей в системі «Творець - людина - природа» у народній педагогіці традиційно використовувалось поняття «Святий». «Святими» в уявленнях народу є Творець і його творіння (Сонце, Небо, Земля, вода, рослини, тварини та хліб). Через ці поняття формувалось уявлення про «святість», тобто цінність, усієї природи.

Традиції були також головним механізмом регулювання поведінки молоді у природі. Включаючи заборони негативної поведінки у формі розповідей чого «не годиться» робити та пояснень про наслідки певних вчинків, традиції надавали поведінці кожної дитини певної спрямованості у відповідності 3 народними вимогами.

Важливою формою регуляції поведінки молоді виступали природоохоронні звичаї, які конкретизували кожну традицію. Педагогічною особливістю звичаїв є те, що вони являють собою стандартизовану форму наслідування поведінки старших. Механізм передачі досвіду за допомогою звичаю полягає в закріпленні певного комплексу дій по відношенню до природи через повторення вже відомих зразків для наслідування прикладу дорослих. 
Звичаї, як форми поведінки, пов'язані з діяльністю практичного характеру. Вони передавали підростаючим поколінням конкретні зразки позитивної поведінки по відношенню до природи та ознайомлювали 3 конкретними видами природоохоронної діяльності. Через дотримання природоохоронних звичаїв відбувалося вправляння молоді у позитивних діях по відношенню до природи та формування навичок раціонального природокористування.

Слід відмітити, що дотримання природоохоронних звичаїв не було «сліпим» та «в силу звички». Більшість звичаїв були пов'язані з конкретними зразками усної народної творчості (легендами, переказами, повір'ями) виховного характеру, які спонукали природоохоронну діяльність. Наприклад, звичай приваблення лелек був пов'язаний $з$ циклом народних повір'їв про те, що лелеки селяться лише поблизу добрих людей і приносять щастя в оселю. Етнограф Д. Мордовцев, помітивши зв'язок між повір'ями та звичаями народу, стверджував, що народ повністю застосовує на практиці свій народний світогляд по відношенню до навколишньої природи.

Традиції та звичаї виступають у народній педагогічній системі як дві взаємопов'язані форми виховного впливу на особистість. Вони виконують спільну орієнтувально-регулятивну функцію по відношенню до молодших поколінь. Здійснюючи безпосередній вплив на свідомість людини, традиції регулюють поведінку через світоглядні уявлення, ідеали та цінності.

Функціонування народних свят та обрядів, у рамках народних виховних традицій було зумовлено об'єктивними духовними та практичними педагогічними потребами, а саме - необхідністю передачі наступним поколінням духовного та господарського досвіду.

Обряди як сукупність традиційних символічних колективних дій, спрямованих на ознаменування, відзначення та закріплення в індивідуальній i колективній свідомості найбільш значимих явищ природи, найважливіших подій в житті людини і сільської общини, сприяли цілісному чуттєво-понятійному й образно-емоційному сприйманню духовних цінностей традицій. Це відбувалось завдяки виникненню різноманітних форм обрядових дій у результаті варіативного поєднання основних компонентів обрядів: вербально-мовного, музичного, дієводинамічного, зовнішнього.

У процесі обрядів відбувалось естетичне сприйняття людиною існуючої природної дійсності, яке супроводжувалось виникненням емоцій, переживань, почуттів, їх взаємним підсиленням і спрямуванням у відповідне традиції русло. Завдяки поєднанню зовнішнього впливу на свідомість 3 емоційним «підкріпленням» забезпечувалось переведення знань у компоненти внутрішнього світу особистості судження, погляди та переконання щодо природи.

Народні свята мали важливе виховне значення, оскільки відображали головні зміни в природі на протязі року. Весняні свята включали зустріч весни та прильоту птахів, вшанування землі, що пробуджується від зимового сну. До літнього циклу народних свят було приурочено вшанування води. що дає життєдайну силу рослинам, вшанування Святої Трійці у період апогею в розвитку вегетації природи, шанування тварин під час «звірових свят». Осінній період був пов'язаний в вшануванням Бога, який дав людині врожай, а також включав свята, пов'язані 3 підготовкою птахів та тварин до зими. Зимові свята символізують вшанування Різдва Христового та бажання заручитися підтримкою Творця на майбутній сільськогосподарський сезон. 
Якщо окремі традиції та звичаї мали конкретне спрямування на виховання бережливого ставлення молоді до окремих компонентів природи (землі, води, рослин, тварин), народні свята, 3 педагогічної точки зору, були багатофункціональними, оскільки виховні впливи здійснювались відразу в кількох напрямках.

Обрядова форма традицій синтезувала в собі різні напрямки природоохоронного виховання і сприяла вихованню дбайливого ставлення до природи як до єдиного цілого. Характерною особливістю народних свят і обрядів була їх наочність, широке використання символів, які унаочнювали основні ідеї духовних традицій. Через систему символів і виразну емоційну форму прояву народного світогляду (музику, пісні, танці, театралізовані дійства) обрядовість викликала у молоді той комплекс морально-естетичних почуттів, на основі якого відбувалось засвоєння духовних цінностей і формування природоохоронних якостей особистості.

Формування природоохоронних якостей забезпечувалось включенням особистості у цілеспрямовану діяльність у відповідності 3 ціннісними і нормативними компонентами традицій через систему звичаїв, які детально регламентують поведінку i трудову діяльність дітей та молоді у природному середовищі в різних життєвих ситуаціях. У результаті засвоєння традицій i дотримання звичаїв відбулось формування певної спрямованості особистості, однією 3 важливих рис якої є відповідальне ставлення до природного середовища.

Висновки. Таким чином, формування у молодших поколінь дбайливого ставлення до природного середовища в народній педагогіці відбувалося в результаті органічного поєднання всіх засобів виховання, включаючи природоохоронні традиції, звичаї, народну обрядовість, усну народну творчість з природоохоронним змістом. Народні природоохоронні традиції виникли в результаті гармонійного життя та активного господарського освоєння людиною природного середовища. Їх формування відбувалось протягом тривалого історичного періоду під впливом духовних, природних і соціально-господарських факторів. Народні природоохоронні традиції $є$ способом вироблення, збереження та передачі із покоління в покоління позитивного етнічного досвіду нашого народу у взаємовідносинах 3 навколишнім природним середовищем.

Традиціями природоохоронного виховання у народній педагогіці вважаємо увесь практичний виховний досвід народу, що включає педагогічний ідеал, цінності, шляхи, засоби, форми, методи і прийоми виховання бережливого, відповідального ставлення до природи, які склалися історично і передавалися 3 покоління в покоління через природоохоронні традиції, звичаї, обряди, свята, символи, ритуали, народний календар, усну народну творчість. Народні природоохоронні традиції $\epsilon$ системним педагогічним явищем з точки зору їх функціональності та змістовності.

\section{ЛІТЕРАТУРА}

Афонина, 1986 - Афонина В. Н. Глобальная экология и проблемы культурной традиции // Взаимодействие общества и природы: Философско-методологические аспекты экологической проблемы. - М.: Наука, 1986. - С. 303-316.

Бегека, 1995 - Бегека А. Д. Природознавчі народні традиції в екологічному вихованні / А. Д. Бегека // Традиції виховання у світовій народній педагогіці: Матеріали Міжнар. Наук.-практ. конф. 68 червня 1995, Рівне. 41 / АПНУ - К.; Рівне, 1995. - С. 16-19.

Бромлей, 1990 - Бромлей Ю., Подольный Р. Человечество - это народы. - М.: Мысль, 1990 - 391 с.

Бромлей, 2008 - Бромлей Ю. В. Очерки теории этноса / Ю. В. Бромлей: - Изд. 2-е, доп. - М., 2008. - 437 с. 
Вербицький, 2003 - Вербицький В. В. Еколого-натуралістична освіта в Україні: історія, проблеми, перспективи. - К., СПМ «Аверс», 2003. - 304 с.

Верхратський, 1869 - Верхратський І. Початки до уложення номенклатури и терминологии природописної, народної. - Львів, 1869. - 40 с.

Гісиова, 1991 - Гісцова Л.З. «Щоб защадевши леса... можно было і напредкы чем корыстоватись» // Архіви України. - 1991. - №5 - 6. - С. 75-84.

Екологічне виховання молодших школярів, 2002 - Екологічне виховання молодших школярів: Навч. пос. для студ. пед. ф-тів і вчит. поч. класів / О.А. Біда, Г.П. Волошина, В.П. Гонзуль. - К.:Наук. світ, 2002. $336 \mathrm{c}$.

Енциклопедія освіти, 2008 - Енциклопедія освіти / Акад. пед. наук України. - К.: Юрінком Інтер, 2008. - 1040 c.

Заглада, 1929 - Заглада Н. Побут селянської дитини. Матеріали до етнології. - К., 1929. - 262 с.

\section{REFERENCES}

Afonina, 1986 - Afonina V. N Global ecology and problems of the cultural tradition // Interaction of society and nature: Philosophical and methodological aspects of the ecological problem. - Moscow: Nauka, 1986. -P. 303-316.

Begeca, 1995 - Begeka AD Natural sciences folk traditions in ecological education / AD Begeca // Traditions of upbringing in world folk pedagogy: Materials of the International. Scientific Conference, Labor Conference, June 6 - 8, 1995, Rivne. 41 / APNU. - K .; Rivne, 1995. - P. 16-19.

Bromley, 1990 - Bromley Yu., Podolny R. Humanity - These are peoples. - M .: Mysl, 1990. - $391 \mathrm{pp}$.

Bromley, 2008 - Bromley Yu.V. Essays on the theory of ethnos / Yu.V. Bromley: - ed. 2nd, add. - M., 2008. - 437 pp.

Verbitsky, 2003 - Verbitsky V.V. Ecological-naturalistic education in Ukraine: history, problems, perspectives. - K., SPM «Avers», 2003. - 304 p.

Verhratsky, 1869 - Verkharty I. The beginning to the enumeration of the nomenclature and the natural folk. - Lviv, 1869. $-40 \mathrm{p}$.

Gitsova, 1991 - Gitsova L.Z. «To forge the forests ... it was possible and in the future than to be used» // Archives of Ukraine. - 1991. - No. 5-6. - P. 75-84.

Environmental education of junior schoolchildren, 2002 - Environmental education of junior pupils: Teach. pos For the studio Ped .. ft-tev and teaches. beginning of classes / O.A. Bida, G.P. Voloshina, VP Gonzul. - K.: Science. World, 2002. - 336 pp.

Encyclopedia of Education, 2008 - Encyclopedia of Education / Acad. ped Sciences of Ukraine. - K .: Yurincom Inter, 2008. - $1040 \mathrm{pp}$.

Zaglad, 1929 - Zaglad N.B. Peasant child. Materials for ethnology. - K., 1929. - 262 pp.

УДК 37.061. 373.5:37.013(561)

DOI 10.31470/2308-5126-2019-45-2-115-122

Злата Соловей, аспірант IV року навчання ДВНЗ «Переяслав-Хмельнииький державний педагогічний університет імені Григорія Сковороди».
Zlata Solovei, postgraduate student of the IV year of the SHEI «Pereiaslav-Khmelnytskyi Hryhorii Skovoroda State Pedagogical University».

E-mail: zlatasolovei@gmail.com

ORCID 0000-0002-1419-3865

\section{РОЛЬ НЕФОРМАЛЬНОЇ ОСВІТИ У ФОРМУВАННІ ТА РОЗВИТКУ КЛЮЧОВИХ КОМПЕТЕНТНОСТЕЙ ОСОБИСТОСТІ (ДОСВІД ТУРЕЧЧИНИ)}

\footnotetext{
У статті розглядаються проблеми неформальної освіти відповідно до досвіду Туреччини. Дається загальне визначенні поняття неформальної освіти та способи ї̈ впровадження. Висвітлюються основні завдання створення та підтримання неформальної освіти як найбільш демократичної та гуманістичної, ніж інші види освіти, щчо передбачає врахування інтересів особистості та ї̈ потреб, сприяє здобуттю освіти всіма охочими, незалежно від віку, статі, сочіального стану та місця проживання. Аналіз наукових досліджень вчених Туреччини щодо розвитку неформальної освіти країни та ї̈ значення для навчання молоді й дорослих надає нам можливість стверджувати, щьо заходи цьього виду освіти направлені перш за все на
} 